\title{
Rare earth elements (REE) and thorium in the youngest Pleistocene glacial tills in Poland
}

\author{
Paweł KWECKO ${ }^{1, *}$ \\ 1 Polish Geological Institute - National Research Institute, Rakowiecka 4, 00-975 Warszawa, Poland
}

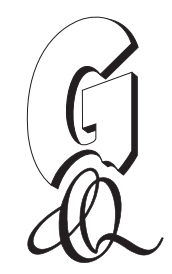

Kwecko, P., 2016. Rare earth elements (REE) and thorium in the youngest Pleistocene glacial tills in Poland. Geological Quarterly, 60 (2): 451-460, doi: 10.7306/gq.1295

The study encompassed outcrops of glacial tills (topsoil, subsoil-1, subsoil-2) of the maximum stadial of the Vistulian Glaciation and of the Wartanian Stadial of the Odranian Glaciation, occurring along the maximum extent of the Vistulian ice sheet. The youngest Polish glacial tills show very similar concentrations of REE and Th. The concentrations of these elements vary across a wide range from $0.08 \mathrm{mg} / \mathrm{kg}$ (Tm and Lu) to $70.3 \mathrm{mg} / \mathrm{kg}(\mathrm{Ce})$, with slightly higher values for the older tills (Wartanian). Both these tills show clear fractionation of LREE and HREE, with a higher and more varied LREE concentration. The most prominent feature distinguishing one till from the other is the distribution of REE fractions along their vertical sections. In the younger (Vistulian) tills the maximum concentration of individual LREE is found at a depth of $1.0 \mathrm{~m}$, and of HREE, Sc and Th, at $2.0 \mathrm{~m}$; while in the older (Wartanian) tills the highest concentrations of all elements investigated are observed at a depth of $1.0 \mathrm{~m}$. Also, the mineral compositions of the tills are very alike. The dominant minerals are quartz (average 56\%) and feldspars (approximately 9\%), with a trend of decreasing concentrations with depth. There are no carbonates in the topsoil $(0.3 \mathrm{~m}$ level), and the clay minerals are dominated by illite (approximately $16 \%)$ and kaolinite (average 5\%). Statistical analysis indicates over a dozen factors determining the concentration of REE and Th in both tills. Three of them have a crucial ( $96 \%$ of total variation) effect on the concentrations of these elements. These factors are probably of geogenic nature, intimately associated with similar source areas, and with similar processes of deposition, diagenesis and weathering of the tills.

Key words: REE, glacial tills, Vistulian ice sheet, Wartanian Stadial.

\section{INTRODUCTION}

The rare earth elements (REE) comprise a group of 15 lanthanides - La, Ce, Pr, Nd, Pm - radionuclide, Sm, Eu, Gd, Tb, Dy, Ho, Er, Tm, Yb, Lu), scandium (Sc) and yttrium (Y) (IUAPC.... 1970; Henderson, 1984; De Vos et al., 2006). The REE are usually divided into two conventionally termed groups: light (LREE) including La through Eu (or occasionally Gd) and heavy (HREE) from Gd (or Tb) through Lu. Most scientists also discriminate a third group that partly overlaps the LREE and HREE: the medium REE (MREE) group that comprises Sm through Ho. Although $Y$ is the lightest REE, it is usually assigned to the HREE due to its physical and chemical similarity (Migaszewski and Gałuszka, 2015).

REE concentration is usually presented not as an absolute value but a normalized value, which allows determining the relative enrichment of environments analysed for these elements. Normalized value is a ratio of analytically determined concentration of an element to its concentration in material of a standard (of meteorite, igneous rock, sedimentary rock, soil). Nor-

\section{*E-mail: pawel.kwecko@pgi.gov.pl}

Received: February 4, 2016; accepted: May 6, 2016; first published online: May 19, 2016 malization is also helpful in analysing both REE fractionation and anomalies by determining their intensity using quantitative indicators based on normalized values. These values are usually presented in the form of graphs that allow for easy determination of the enrichment/depletion of a group or of a single element (Laveuf and Cornu, 2009). Horizontal line of normalized REE concentration denotes there is no enrichment, and its rising/falling trend along a given stretch indicates there is an enrichment/depletion in the element (or a group of REE).

The frequency of REE occurrence in nature is greater than of many rare metals, and their distribution in rocks and soils is the subject of a growing number of non-economic geology studies. REE are a useful tool in geodynamic (e.g., Galbarczyk-Gassiorowska, 2010), palaeogeographical (e.g., Singh and Rajamani, 2001) and stratigraphic (e.g., Długosz, 2002) studies. The paper by Fedele et al. (2008) presents the contents of REE distribution in soils (and floodplain and stream sediments) across Europe. These authors used data from the geochemical atlas of Europe (De Vos et al., 2006) developed within the framework of the FOREGS project. In previous geochemical studies of sedimentary deposits in Poland, REE were not a common subject of interest (Duczmal-Czernikiewicz, 2012; Małecka, 2012; Bojakowska et al., 2013) and have not been so far used in the stratigraphic correlation of Quaternary deposits. This study provides an attempt to answer the question of whether it is feasible to use variations in REE concentrations in sections of these tills for stratigraphic studies in areas of late-glacial relief, and how the 
various REE (LREE, HREE) and Th concentrations in these sections can support mapping surveys.

This paper presents an analysis of the distribution of REE (and Sc, Y and Th) concentrations in glacial tills of the youngest glaciations (the maximum stadial of the Vistulian Glaciation and the Wartanian Stadial of the Odranian Glaciation) in Poland. The chemical and mineral composition of glacial tills depends mostly on the great lithological variability of mother host rocks (the hard bedrock of the Baltic Sea Basin and Scandinavia) eroded by the ice sheet. The tills of both glaciations are similar in terms of source areas, processes of deposition, diagenesis and weathering, but differ in the duration of weathering.

The most common division of REE into two subgroups is used in this paper: LREE (light rare earths) ranging from La to $\mathrm{Eu}$, which includes elements of more alkaline properties, and HREE (heavy rare earths) from Gd to Lu and Y, showing less alkaline properties (Charewicz, 1990).

According to the Polish stratigraphy as currently valid - Instructions of Detailed Geological Map of Poland in scale 1:50,000 (Instrukcja..., 2004), the older tills represent the Wartanian Glaciation, however, their stratigraphic rank has recently been reduced to the Wartanian Stadial of the Odranian Glaciation (Gałązka et al., 1999; Lindner and Marks, 2012) and such a stratigraphic position of the older tills is adopted in this paper.

\section{STUDY AREA AND METHODS}

The study area is located in northern Poland and covers outcrops of the youngest Quaternary tills of the Odranian Glaciation (Middle Polish Complex) and the Vistulian Glaciation (North Polish Complex). Eight test areas (moving from the east): VI, I, II, VIII, III, VII, IV and V (numbering in chronological order; Fig. 1), were marked out along the maximum extent of the Vistulian ice sheet (Marks, 2002).

The areas of sampling sites were selected based on selected Polish geological map sheets at a scale of 1:50,000. After verification of the lithology of sediments exposed on the surface, the areas were marked out so that each of them covered outcrops of tills of the Main Stadial of the Vistulian Glaciation (younger tills) and of the Wartanian Stadial of the Odranian Glaciation (older tills) (Marks, 2005).

Rock samples for the analysis were taken from lodgement till (deposited from active ice under the ice sheet) or melt-out till (rock material deposited from stagnant ice; Lisicki, 2003; Kenig, 2009). These are compact plastic (or hard plastic) tills containing a variety of lithological admixture of igneous, metamorphic and sedimentary rocks. They comprise a broad spectrum of poorly sorted tills: sandy, sandy with gravel, silty, sandy-silty, silty with gravel (pebbles). The great diversity of textural and structural

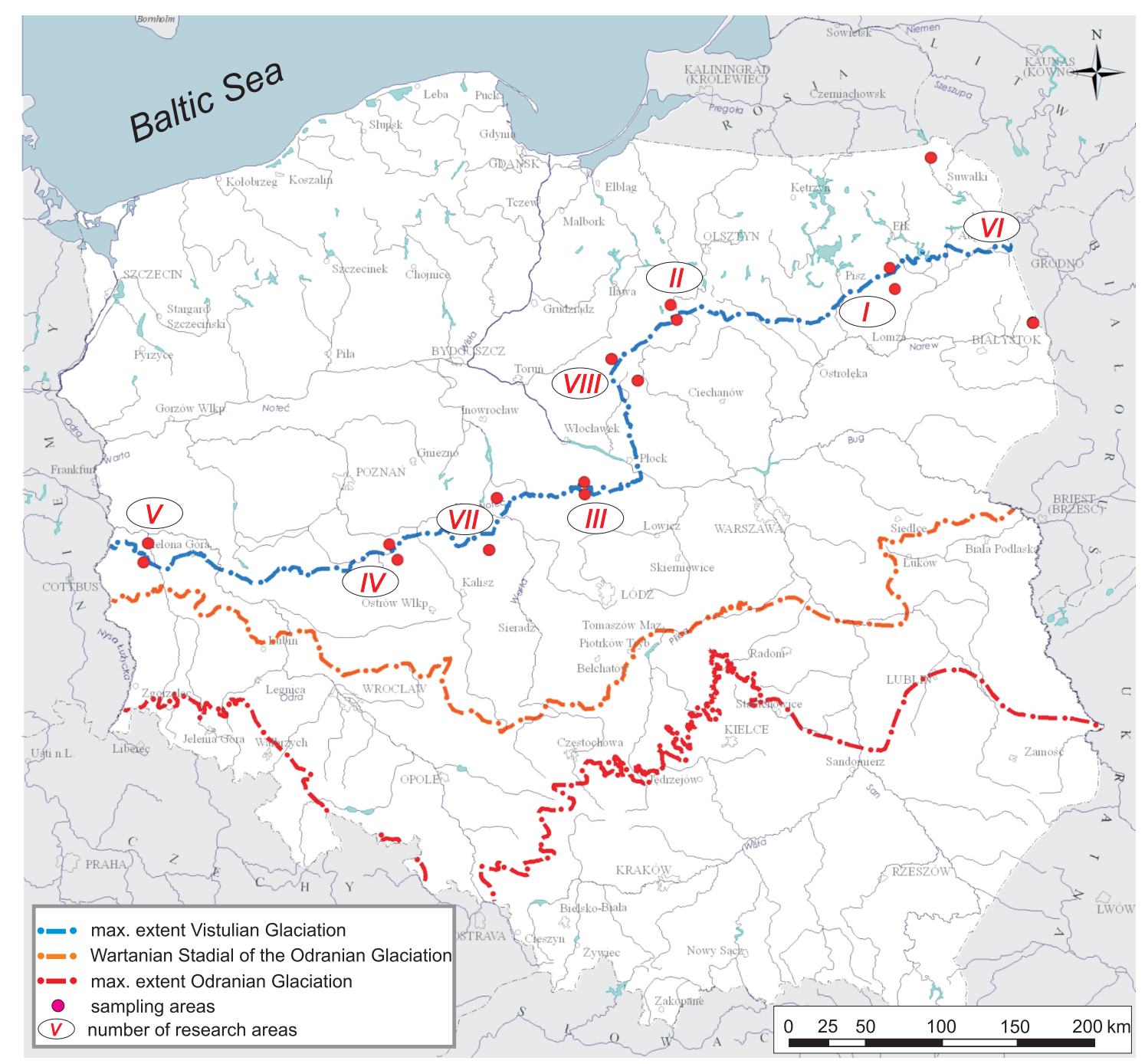

Fig. 1. Location of the study areas 
features of the tills made it impossible to distinguish the characteristic lithology (lithotype) for a given area, level or glaciation.

Field work. In each test area, three hand-drilled boreholes (by a standard hand auger set) were undertaken to a depth of $2 \mathrm{~m}$ in the younger tills (maximum stadial of the Vistulian Glaciation), and three in the older tills (Wartanian Stadial of the Odranian Glaciation). Approximately $500 \mathrm{~g}$ samples were collected from tills of each borehole, at depth ranges of $0.0-0.3 \mathrm{~m}$, $1.0-1.3 \mathrm{~m}$, and $1.8-2.0 \mathrm{~m}$. These three levels are referred to hereinafter as topsoil, subsoil-1, subsoil-2. Referring to the current taxonomy of Polish soils (Systematyka..., 2011), these three horizons generally can be associated with levels of soil: topsoil to the level of humus (A), subsoil-1 with the level of leaching $(E)$ and the subsoil-2 with level of enrichment (B). A total of 48 boreholes were drilled and a total of 144 till samples were taken.

Laboratory work. After crushing and quartering, the till samples were ground in agate ball mills to the $<0.06 \mathrm{~mm}$ fraction. Sample mineralisation was carried out in a mixture of $\mathrm{HNO}_{3}+\mathrm{HClO}_{4}+\mathrm{HF}$, and the concentrations of REE (La, Ce, $\mathrm{Pr}, \mathrm{Nd}, \mathrm{Sm}, \mathrm{Eu}, \mathrm{Gd}, \mathrm{Tb}, \mathrm{Dy}, \mathrm{Ho}, \mathrm{Er}, \mathrm{Tm}, \mathrm{Yb}, \mathrm{Lu}, \mathrm{Sc}$ and $\mathrm{Y}$ ) and Th were determined by the ICP-MS method.

Most of the samples (108) were also analysed for determination of mineral composition using the XRD method after separation of the clay fraction $(<0.02 \mathrm{~mm})$. Oriented air-dry glycolated and heated (at $550^{\circ} \mathrm{C}$ ) samples were analysed. Percentage concentrations of the individual phases were semi-quantitatively evaluated by an external standard method (by comparing the intensity of analytical peaks of minerals on X-ray graphs of standard samples and examined samples).

Statistical analysis. The following statistical parameters were used to assess the nature of the distribution of elements studied: distribution interval $(\Delta=\min -\max )$, distribution centre [a $=(\min +\max ) / 2]$, minimum to maximum value ratio $(\varnothing=$ $\mathrm{min} / \mathrm{max}$ ), standard deviation (s) and skewness index distribution (q). The results of these indicators comply with the criteria of normal distribution ( $\varnothing>0.1 ; \mathrm{m}-\mathrm{w}<\mathrm{s} ; 3<\Delta / \mathrm{s}<5$; $\mathrm{q}<2$ ) (Mazerski, 2009), thus the median and the arithmetic mean are considered as the representations of central tendency, and the standard deviation as the dispersion index (Table 1).

\section{RESULTS}

Mineral composition of the clay fraction in the glacial tills. The clay fraction $(<0.02 \mathrm{~mm})$ of the tills of both glaciations is characterized by low qualitative and quantitative variability. Both the younger and the older tills are dominated by quartz, accompanied by feldspars. The quartz content is estimated at $50-65 \%$ (average 56\%) and the feldspar content at 8-10\% (average $9 \%$ ) with a trend of decreasing contents of both minerals with depth. The majority of samples reveal the presence of calcite and dolomite, but the characteristic feature is the lack of carbonates in the surface level (topsoil). In both tills, illite is the most common mineral ( $16 \%)$, followed by kaolinite ( $5 \%$ on average). In the deeper zones (subsoil-1, and subsoil-2) the contents of these minerals are higher compared to the surface level (topsoil), however, it is slightly higher in the older tills (Wartanian). The amounts of vermiculite, montmorillonite and chlorites are similar in the tills from both glaciations (an average of 2, 4 and $3 \%$, respectively), with the highest content in the topsoil and slightly higher contents in the younger tills (Vistulian). Common minerals are amphiboles accompanied, but only in the Vistulian tills and in trace amounts, by serpentine, magnetite and talc. Mixed-layered minerals of chlorite/vermiculite type are found in the whole section of the younger tills (Vistulian), whereas in the older tills (Wartanian) they occur only at subsoil-1.

Concentrations of REE and Th. The concentrations of these elements vary in a wide range from $0.08 \mathrm{mg} / \mathrm{kg}$ ( $\mathrm{Tm}$ and $\mathrm{Lu}$ ) to $70.3 \mathrm{mg} / \mathrm{kg}(\mathrm{Ce})$, while the average and median values in the Vistulian and Wartanian tills are similar (both in the entire sections and in topsoil and subsoils), like the other statistical parameters of the LREE and HREE concentrations. Generally, slightly higher concentrations of the elements analysed are found in the older tills (Wartanian Stadial of the Odranian Glaciation; Table 1).

As regards the vertical sections of both the younger and older tills, the lowest concentrations of the elements are characteristic of the surface level (topsoil), whereas the maximum concentrations show a different distribution and occur at various depths depending on the age. In the younger tills (Vistulian), subsoil-1 shows the highest concentrations of most LREE (La, $\mathrm{Ce}, \mathrm{Pr}, \mathrm{Nd}$ and $\mathrm{Sc}$ and Th), while subsoil-2 has the HREE (including Eu) concentrations. However, in the older tills (Odranian) the maximum concentrations of all elements investigated occur in subsoil-1 (Table 1).

Both the Vistulian and Wartanian tills clearly show differences in the concentrations of REE and Th, depending on the geographic location. In eastern Poland the concentrations are much higher than in the west. The highest concentrations of REE and Th were recorded in the Vistulian till in region I. In the older tills (Wartanian), enrichment in Sc, $\mathrm{Y}$ and $\mathrm{Ce}$ is observed in area I, while the highest concentrations of other LREE (and HREE) and Th are found more to the east, in area VI. The lowest concentrations of the elements analysed in the tills of both glaciations were found in the western area IV (Table 2).

\section{INTERPRETATION}

The smallest concentrations of REE and Th in the topsoils of both tills are probably the result of weathering and pedogenic processes (argilluviation, migration with organic matter and Fe-Mn oxides). Low $\mathrm{pH}$ values favour this process, and about $60 \%$ of the Polish soils is very acidic, acidic and slightly acidic ( $\mathrm{pH} \leq 6.7$; Lis and Pasieczna, 1995). REE removed by soil solutions from the upper part of weathered zone are incorporated (to varying degrees) into new minerals (Öhlander et al., 1996; Panahi et al., 2000; Taunton et al., 2000; Gnandi and Tobschall, 2003) that precipitated at deeper levels to enrich the lower zones of the section with these elements (Braun et al., 1993; Nesbitt and Markovics, 1997; Ma et al., 2002).

Concentration of LREE in weathered material due to the easier release of HREE to migrating solutions (Elderfield et al., 1990; Kabata-Pendias and Mukherjee, 2007; Galbarczyk-Gassiorowska, 2010), reported in weathering processes, is also seen to occur in both the glacial tills. This is indicated by a decreasing ratio of LREE/HREE fractionation with increasing depth. The lowest REE concentration in the upper part of the section confirms the general phenomenon of decreasing REE concentrations with the increasing degree of rock weathering (Bonnot-Courtois, 1981; Boulangé and Colin, 1994; Öhlander et al., 1996; Taunton et al., 2000). In the deposits analysed, this pattern can be linked with the occurrence of the maximum concentration of LREE in the subsoil-1 of both tills.

The most important feature to distinguish between the two tills is the presence of the maximum concentration of HREE and Eu at different depths. In the older tills (Wartanian) the peak concentration occurs in subsoil-1, while in the younger tills (Vistulian) 


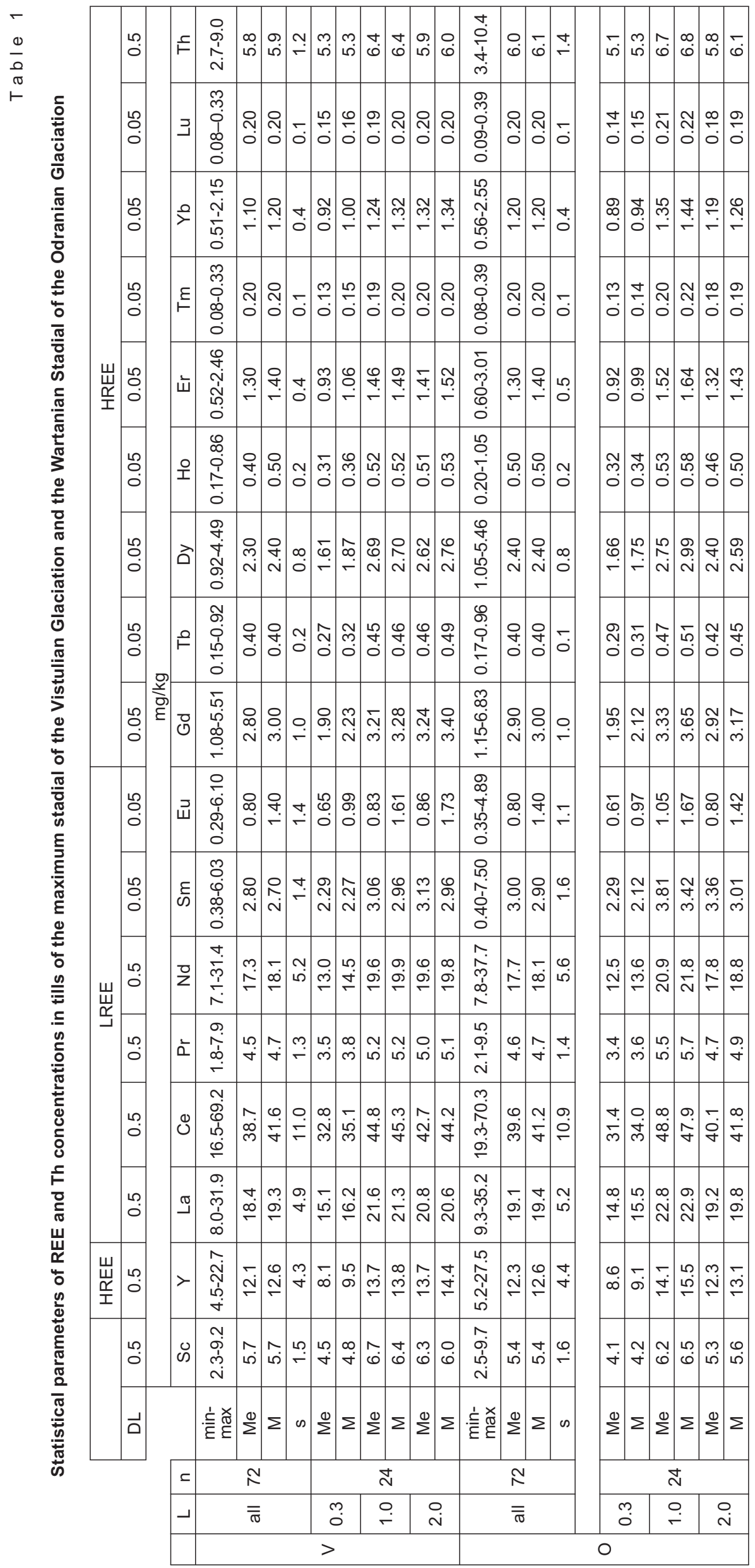


REE and Th concentrations in tills of the maximum stadial of the Vistulian Glaciation and the Wartanian Stadial of the Odranian Glaciation in the study areas

\begin{tabular}{|c|c|c|c|c|c|c|c|c|c|c|c|c|c|c|c|c|}
\hline & \multicolumn{8}{|c|}{ max. stadial (Vistulian) } & \multicolumn{8}{|c|}{ Wartanian stadial (Odranian) } \\
\hline & $\mathrm{V}$ & IV & VII & III & VIII & II & $\mathrm{I}$ & $\mathrm{VI}$ & $\mathrm{V}$ & IV & VII & III & VIII & II & I & $\mathrm{VI}$ \\
\hline & \multicolumn{8}{|c|}{$\mathrm{W}-\mathrm{C}$} & \multicolumn{8}{|c|}{ W - areas } \\
\hline & \multicolumn{8}{|c|}{$\mathrm{mg} / \mathrm{kg}$} & \multicolumn{8}{|c|}{$\mathrm{mg} / \mathrm{kg}$} \\
\hline Sc & 5.1 & 4.8 & 5.7 & 6.1 & 5.5 & 6.0 & 7.4 & 5.4 & 6.0 & 4.7 & 5.1 & 5.8 & 4.6 & 5.5 & 6.5 & 5.4 \\
\hline $\mathrm{Y}$ & 10.0 & 9.5 & 12.9 & 12.4 & 12.9 & 13.0 & 15.3 & 14.6 & 13.2 & 9.2 & 11.5 & 11.7 & 11.5 & 12.9 & 15.7 & 14.9 \\
\hline La & 16.8 & 15.2 & 19.5 & 16.6 & 20.8 & 19.4 & 23.8 & 22.6 & 21.1 & 14.0 & 18.5 & 17.3 & 17.5 & 20.2 & 23.0 & 23.5 \\
\hline $\mathrm{Ce}$ & 35.5 & 32.5 & 40.9 & 36.2 & 42.5 & 43.8 & 53.0 & 47.9 & 44.6 & 30.0 & 37.6 & 36.5 & 35.3 & 46.5 & 49.8 & 49.2 \\
\hline $\mathrm{Pr}$ & 4.1 & 3.7 & 4.7 & 4.2 & 5.1 & 4.7 & 5.8 & 5.4 & 5.1 & 3.4 & 4.4 & 4.2 & 4.2 & 4.9 & 5.6 & 5.8 \\
\hline $\mathrm{Nd}$ & 15.8 & 14.6 & 17.9 & 16.0 & 19.6 & 18.1 & 21.8 & 20.9 & 19.6 & 13.0 & 17.1 & 15.9 & 15.9 & 19.0 & 21.6 & 22.3 \\
\hline $\mathrm{Sm}$ & 3.0 & 2.7 & 0.7 & 3.0 & 0.8 & 3.5 & 4.2 & 3.9 & 3.7 & 2.5 & 0.7 & 3.1 & 0.7 & 3.7 & 4.2 & 4.3 \\
\hline $\mathrm{Eu}$ & 0.6 & 0.6 & 3.4 & 0.7 & 3.7 & 0.7 & 0.9 & 0.9 & 0.8 & 0.6 & 3.2 & 0.7 & 3.0 & 0.8 & 0.9 & 0.9 \\
\hline $\mathrm{Gd}$ & 2.6 & 2.3 & 2.9 & 2.7 & 3.2 & 3.0 & 3.6 & 3.5 & 3. & 2. & 2.8 & 2. & 2.6 & 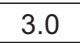 & 3.6 & 3.7 \\
\hline $\mathrm{Tb}$ & 0.4 & 0.3 & 0.4 & 0.4 & 0.5 & 0.4 & 0.5 & 0.5 & 0.5 & 0.3 & 0.4 & 0.4 & 0.4 & 0.4 & 0.5 & 0.5 \\
\hline Dy & 2.0 & 2.0 & 2.5 & 2.2 & 2.6 & 2.5 & 3.0 & 2.7 & 2.4 & 1.9 & 2.2 & 2.3 & 2.2 & 2.6 & 3.0 & 3.0 \\
\hline $\mathrm{Ho}$ & 0.4 & 0.4 & 0.5 & 0.4 & 0.5 & 0.5 & 0.6 & 0.5 & 0.5 & 0. & 0.4 & 0.4 & 0.4 & 0.5 & 0.6 & 0.6 \\
\hline $\mathrm{Er}$ & 1.1 & 1.1 & 1.4 & 1.2 & 1.4 & 1.4 & 1.7 & 1.5 & 1.3 & 1.0 & 1.2 & 1.2 & 1.2 & 1.5 & 1.7 & 1.7 \\
\hline $\mathrm{Tm}$ & 0.2 & 0.1 & 0.2 & 0.2 & 0.2 & 0.2 & 0.2 & 0.2 & 0.2 & 0.1 & 0.2 & 0.2 & 0.2 & 0.2 & 0.2 & 0.2 \\
\hline $\mathrm{Yb}$ & 1.0 & 1.0 & 1.3 & 1.1 & 1.3 & 1.2 & 1.4 & 1.4 & 1.2 & 0.9 & 1.2 & 1.1 & 1.2 & 1.3 & 1.4 & 1.5 \\
\hline Lu & 0.2 & 0.2 & 0.2 & 0.2 & 0.2 & 0.2 & 0.2 & 0.2 & 0.2 & 0. & 0.2 & 0.2 & 0.2 & 0.2 & 0.2 & 0.2 \\
\hline Th & 5.6 & 4.8 & 5.7 & 5.4 & 5.9 & 6.2 & 6.7 & 7.1 & 7.0 & 4.8 & 5.6 & 5.8 & 5.0 & 6.5 & 6.6 & 7.2 \\
\hline
\end{tabular}

it is in subsoil-2. The differences relate mainly to the average values and, to a lesser extent, to the median values. These differences are relatively small; however, it is difficult to clearly identify the causes of the recorded higher HREE concentration at a greater depth in the younger deposits. This may result from the diverse distribution of mixed-layered minerals of chlorite/vermiculite type observed through the whole section of the younger tills (Vistulian). Whereas, in the older tills (Wartanian) this only refers to subsoil-1, bearing in mind that smectite and chlorite are enriched in HREE, while illite and vermiculite are enriched in LREE. This can also be a result of a process affecting the distribution of primary silica minerals (e.g., garnets, hornblende, orthopyroxene), which are richer in HREE (Kanazawa and Kamitani, 2006), or the distribution of "deposit-forming" REE minerals such as bastnäsite, monazite, loparite (enriched in LREE) or xenotime and apatite (enriched in HREE) (Zepf, 2013; Ryder and Nowak, 2015). A decrease in the proportion of primary carbonates can also cause enrichment in HREE (Reeder and America, 1983), and the tills of both glaciations contain carbonates in deeper zones (except topsoil) of the vertical section. The available study

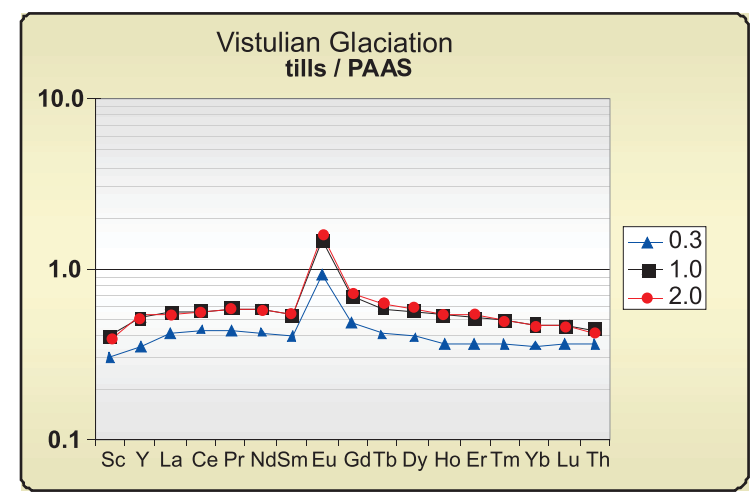

results are insufficient to resolve this question, resolution of which requires further research.

REE in sedimentary rocks are generally normalized to two standards: post-Archean Australia Shale - PAAS (Taylor and McLennan, 1985; Fedele et al., 2008) and North American Shale Composite - NASC (Gromet et al., 1984). Additionally, the analysis of normalized concentration of REE and Th was performed for the Vistulian and Wartanian tills with reference to the averaged composition of subsoil and topsoil in the area of Poland (FOREGS) (De Vos et al., 2006) and chondrite (Taylor and McLennan, 2009).

Normalization relative to PASS (Fig. 2) and NASC (Fig. 3) presents a very similar result. The content of REE and Th shows a sharp depletion (except for Eu) in Vistulian and Wartanian tills at all levels. Both of the normalizations expressly indicate the lowest abundance of all elements analysed in the topsoil level and a slightly greater range of diversity of contents deeper (subsoil-1 and subsoil-2) in the older tills (Wartanian).

Normalization to soils (subsoil: $0.5-2.0 \mathrm{~m}$ and topsoil: $0.25 \mathrm{~m}$ ) from Poland (FOREGS) indicates an enrichment of the

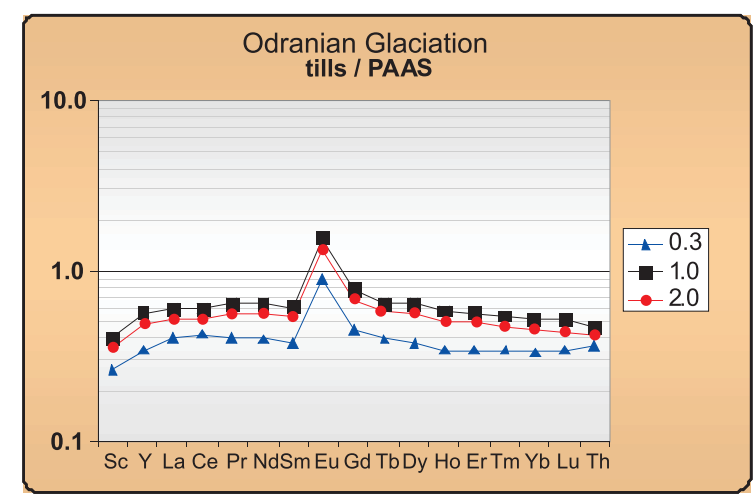

Fig. 2. PASS-normalized (Taylor and McLennan, 1985) REE and Th concentrations in tills of the Vistulian (maximum stadial) and Odranian (Wartanian Stadial) glaciations 

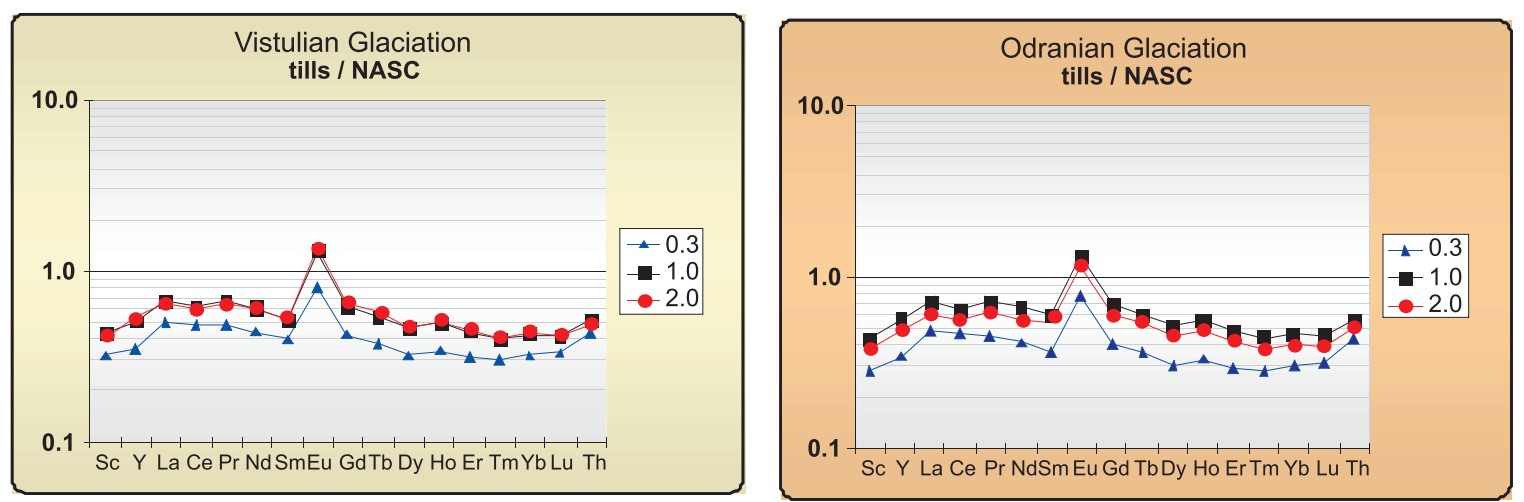

Fig. 3. NASC-normalized (Gromet et al., 1984) REE and Th concentrations in tills of the Vistulian (maximum stadial) and Odranian (Wartanian Stadial) glaciations

tills in REE, albeit to a limited extent. This is not surprising, bearing in mind that most of brown earth soils (over $50 \%$ ) and podsols (about $26 \%$ ) of Poland have developed on moraine tills and loamy sands, and weathering and pedogenic processes have impoverished these deposits in relation to the parent rock. The enrichment does not involve the concentrations of $Y, T m$, $\mathrm{Yb}$ and Lu in both of the glacial tills nor of Dy, Ho and Er in the topsoil $(0.3 \mathrm{~m})$ of the older till (Wartanian). The characteristic feature of this normalization is a very clear positive Eu anomaly indicating an enrichment in both tills of this element, and a greater diversity of HREE concentration in the older tills of the Wartanian Stadial of the Odranian Glaciation (Fig. 4).

The most universal and most commonly used chondrite normalization (Nakamura, 1974; De Vos et al., 2006; Taylor and McLennan, 2009) showed a significant REE enrichment of the tills of both glaciations. It indicated LREE/HREE fractionation, LREE enrichment, positive Eu anomaly, considerable enrichment in Th, and depletion in Sc in both tills (Fig. 5).

Normalizations to sedimentary rocks generally show a depletion in the tills of both glaciations of REE and Th. This may show that the depletion is caused by specific conditions of weathering of "REE-bearing" minerals which, dissolved and leached, are subsequently precipitated as secondary minerals in deeper zones of the section or transferred to other glacial deposits.

All the concentration normalizations for REE and Th in both of the tills indicate: Eu enrichment, REE and Th concentration diversity in the sections (higher in the older tills), and fractionation of these elements.

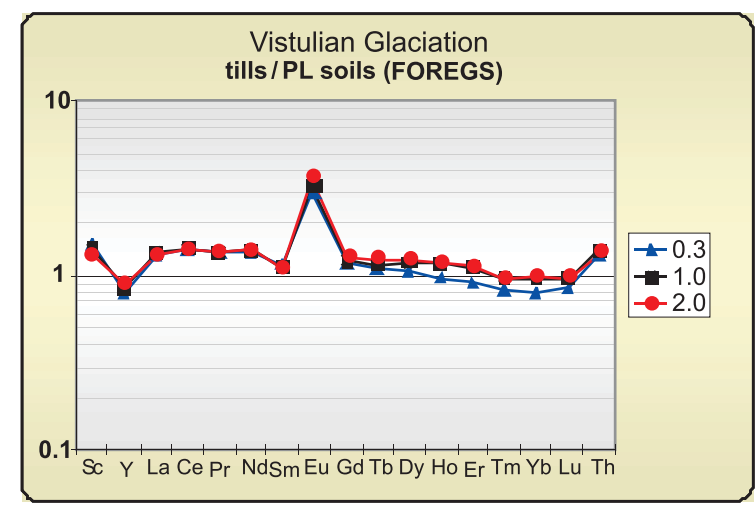

The europium anomaly $\left(\mathrm{Eu} / \mathrm{Eu}^{*}\right)$ is the ratio of determined Eu concentration to its expected (normalized) concentration (McLennan and Taylor, 2012). It is theoretically determined by interpolating the concentrations of two adjacent rare earth elements (by their position in the periodic table) and using chondrite-normalized values.

The $\mathrm{Eu} / \mathrm{Eu}^{*}$ value indicates an enrichment in the tills of both glaciations of this element in all depth ranges analysed in this study. In the younger tills (Vistulian) the value of this positive anomaly increases with depth (from 1.3 to $1.7 \mathrm{~m}$ ), while in the older tills it has a constant value (1.4) along the whole section.

The occurrence of a positive Eu anomaly in the tills of both glaciations is in contradiction with the negative (and significant) $\mathrm{Eu} / \mathrm{Eu}^{*}$ trend observed in upper mantle rocks (McDonough and Sun, 1995) and in soils developed on sedimentary rocks (Chen and Yang, 2010). Increased concentration of Eu in sedimentary rocks is most often interpreted as inherited from parent igneous rocks (Taylor and McLennan, 1985; Awwiller, 1994; Nyakairu and Koeberl, 2001; McLennan and Taylor, 2012), mainly acid rocks (Terekhov and Shcherbakova, 2006) which abound in Eu, and this is probably the cause of this anomaly in both glacial tills.

This observation is supported by studies of glacial tills in Sweden - one of the main source areas of rock material transported by ice streams and lobes to Poland. The REE and Th concentrations determined in those tills is almost twice as high as those found in the Vistulian and Wartanian tills of Poland. The Eu anomaly in the tills of Sweden marks mineralisation zones in that area, with dominant minerals such as allanite,

Fig. 4. FOREGS-normalized (De Vos et al., 2006) REE and Th concentrations in tills of the Vistulian (maximum stadial) and Odranian (Wartanian Stadial) glaciations 

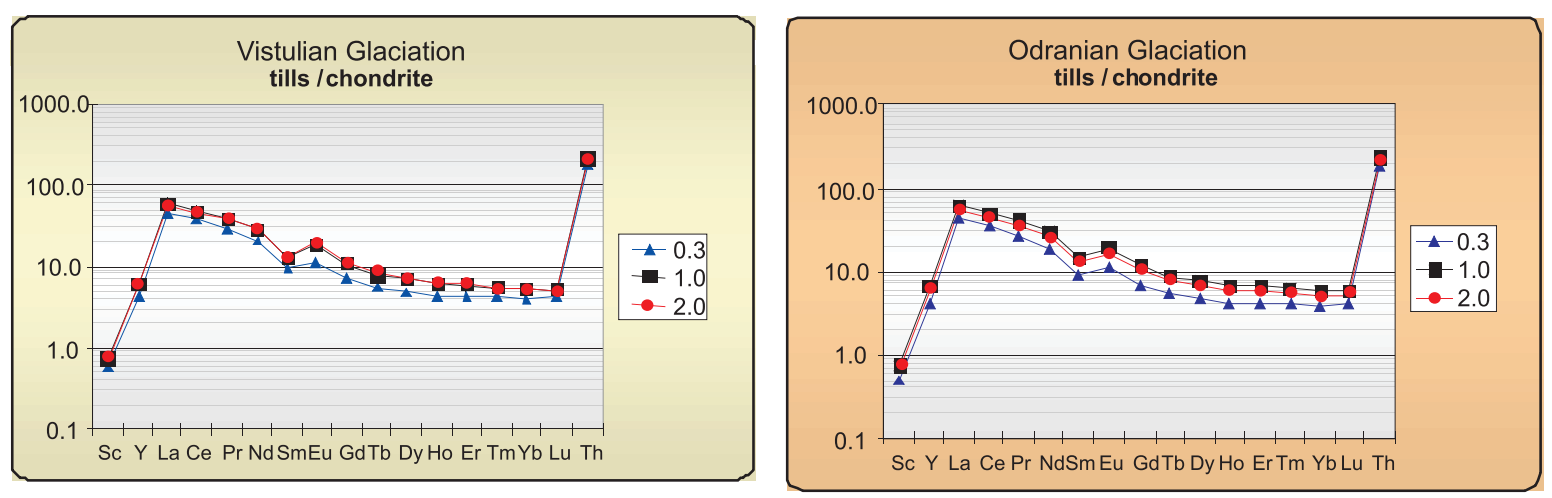

Fig. 5. Chondrite-normalized (Taylor and Mac Lennan, 2009) concentrations of REE and Th in tills of the Vistulian (maximum stadial) and Odranian (Wartanian Stadial) glaciations

bastnäsite, monazite, apatite, zircon and fluorite, which are rich in Eu (Anderson et al., 2014).

Another explanation for the positive europium anomaly in both tills may be the presence of plagioclases in their composition. Feldspars, as the only primary minerals, are characterized by the presence of a positive Eu anomaly (Chase et al., 1963; Towell et al., 1969; Henderson, 1984; Aubert et al., 2001; Compton et al., 2003; Galán et al., 2007). The content of feldspars in the tills examined is significant ( $9 \%)$ and these minerals are relatively highly prone to weathering processes, which may cause mobilization and accumulation of Eu in secondary minerals (illites or smectites) that are relatively common constituents of the tills $(-16 \%$ illite). Certainly, the processes of weathering, formation of secondary minerals, and transportation into deeper zones of the tills may have also significantly affected the formation and differentiation of Eu anomaly values (Table 3 ), although their contribution is difficult to estimate.

The tills of both glaciations were analysed for REE fractionation - the separation into light elements (LREE: La-Ce-Pr-Nd-Pm-Sm-Eu) and heavy elements (HREE: Gd-Tb-Dy-Ho-Er$\mathrm{Tm}-\mathrm{Yb}-\mathrm{Lu}+\mathrm{Y}$ ) using chondrite-normalized values (Taylor and McLennan, 2009) and La/Lu, La/Yb ratios.

The ratios have similar values for the tills of both glaciations and point to marked fractionation of the elements. In both the younger and the older tills, the enrichment in LREE is over three times greater as compared to HREE (average 3.3), and the LREE/HREE ratio slightly decreases with depth. Analysis of the $\mathrm{La} / \mathrm{Lu}$ and $\mathrm{La} / \mathrm{Yb}$ ratios indicates an over ten-fold depletion of the tills in Lu and Yb (HREE) as compared with La (LREE), with a slight variation of these ratios in the vertical section of both tills. In the older tills (Wartanian) the La/Yb ratio decreases with depth (from 11.2 to 10.6), while in the younger tills (Vistulian) the ratio has a value of 10.9 in the topsoil and subsoil-1 (Table 3 ).

The decreasing LREE/HREE fractionation with depth and higher values of fractionation ratios of the older tills (Wartanian) suggest that the enrichment in LREE is due mainly to weathering processes resulting in easier dissolution and migration of HREE in the section, causing a "passive" concentration of LREE, as shown by many earlier studies (Nesbitt, 1979; Duddy, 1980; Topp et al., 1984; Braun et al., 1990; Xing and Dudas, 1993; Boulangé and Colin, 1994; Ma et al., 2002; Compton et al., 2003).

Relationships between the elements analysed were determined by the Pearson's correlation coefficient ( $r$ ). For most of the elements the $r$ values were $>0.9$ (statistical significance $p$ $<0.05$ ), indicating a very strong similarity of the distributions of REE and Th elements in the till sections of both glaciations. This pattern may indicate a similar (mainly qualitative) composition of source material and similar processes of transport, deposition and diagenesis of glacial material during both glaciations. The Wartanian tills of the Odranian Glaciation show a slightly greater proportion of higher values of the correlation coefficient, indicates a stronger relationship of REE as a group in the older tills, which may be related to a higher degree of sediment diagenesis.

In order to identify the likely sources of REE in the tills, a factor analysis was performed on raw data using the Varimax method. The analysis shows that there are three factors that have a critical effect on the REE distributions in the tills of both glaciations defining $>96 \%$ of the total variation (Table 4 ).

The contribution of the effect of the first factor to the distribution of REE is $>80 \%$, and this factor influences the concentrations of not only HREE and $\mathrm{Gd}$ but also Nd, Pr, La in the tills of

Values of $\mathrm{La} / \mathrm{Yb}, \mathrm{La} / \mathrm{Lu}, \mathrm{Ce}$ and Eu anomalies and LREE/HREE (chondrite-normalized) fractionation ratios in tills of the maximum stadial (Vistulian) and the Wartanian Stadial (Odranian)

\begin{tabular}{|c|c|c|c|c|c|c|c|}
\hline & & Level & $\mathrm{La} / \mathrm{Yb}$ & La/Lu & $\mathrm{Ce} / \mathrm{Ce}^{*}$ & Eu/Eu* & LREE/HREE \\
\hline \multirow{4}{*}{$\begin{array}{l}\text { max. st. } \\
\text { Vistulian }\end{array}$} & $\mathrm{n}=72$ & $0.3-2.0$ & 10.7 & 10.7 & 1.0 & 1.5 & 3.3 \\
\hline & \multirow{3}{*}{$\mathrm{n}=24$} & 0.3 & 10.9 & 10.5 & 1.0 & 1.3 & 3.5 \\
\hline & & 1.0 & 10.9 & 11.0 & 1.0 & 1.6 & 3.4 \\
\hline & & 2.0 & 10.4 & 10.7 & 1.0 & 1.7 & 3.2 \\
\hline \multirow{4}{*}{$\begin{array}{l}\text { Wartanian st. } \\
\text { Odranian }\end{array}$} & $\mathrm{n}=72$ & $0.3-2.0$ & 10.8 & 10.9 & 1.0 & 1.4 & 3.3 \\
\hline & \multirow{3}{*}{$\mathrm{n}=24$} & 0.3 & 11.2 & 10.7 & 1.1 & 1.4 & 3.5 \\
\hline & & 1.0 & 10.8 & 10.8 & 1.0 & 1.4 & 3.3 \\
\hline & & 2.0 & 10.6 & 10.8 & 1.0 & 1.4 & 3.3 \\
\hline
\end{tabular}


rocks. The main source material for tills is the hard

Factor eigenvalues, cumulative value, and factor coordinates of REE and Th concentrations in tills of the maximum stadial (Vistulian) and the Wartanian Stadial (Odranian)

\begin{tabular}{|c|c|c|c|c|c|c|c|}
\hline \multicolumn{4}{|c|}{ max. stadial - Vistulian } & \multicolumn{4}{|c|}{ Wartanian Stadial - Odranian } \\
\hline & \multicolumn{3}{|c|}{ FACTOR } & & \multicolumn{3}{|c|}{ FACTOR } \\
\hline & 1 & 2 & 3 & & 1 & 2 & 3 \\
\hline eigenvalue & 14.10 & 1.69 & 0.56 & eigenvalue & 14.44 & 1.51 & 0.45 \\
\hline$\%$ of total & 82.95 & 9.91 & 3.27 & $\%$ of total & 84.95 & 8.90 & 2.64 \\
\hline $\begin{array}{l}\text { cumulative } \\
\% \text { of total }\end{array}$ & 82.95 & 92.86 & 96.14 & $\begin{array}{l}\text { cumulative } \\
\% \text { of total }\end{array}$ & 84.95 & 93.85 & 96.49 \\
\hline Lu & 0.916 & -0.040 & 0.316 & $\mathrm{Er}$ & 0.925 & 0.052 & 0.277 \\
\hline Ho & 0.913 & 0.017 & 0.290 & Ho & 0.921 & 0.048 & 0.269 \\
\hline $\mathrm{Er}$ & 0.912 & 0.016 & 0.310 & $\mathrm{Tm}$ & 0.918 & -0.031 & 0.312 \\
\hline $\mathrm{Tm}$ & 0.910 & -0.057 & 0.333 & Dy & 0.917 & 0.048 & 0.286 \\
\hline $\mathrm{Yb}$ & 0.908 & -0.060 & 0.345 & Lu & 0.910 & -0.001 & 0.315 \\
\hline Dy & 0.906 & 0.011 & 0.290 & $\mathrm{Yb}$ & 0.907 & -0.021 & 0.337 \\
\hline $\mathrm{Y}$ & 0.905 & 0.025 & 0.251 & Gd & 0.905 & 0.039 & 0.328 \\
\hline $\mathrm{Gd}$ & 0.902 & 0.010 & 0.316 & Y & 0.894 & 0.002 & 0.230 \\
\hline $\mathrm{Tb}$ & 0.878 & 0.010 & 0.305 & $\mathrm{~Tb}$ & 0.877 & 0.055 & 0.334 \\
\hline $\mathrm{Nd}$ & 0.829 & 0.000 & 0.424 & $\mathrm{Nd}$ & 0.870 & 0.038 & 0.417 \\
\hline $\operatorname{Pr}$ & 0.801 & 0.011 & 0.457 & $\operatorname{Pr}$ & 0.850 & 0.045 & 0.439 \\
\hline $\mathrm{La}$ & 0.752 & -0.007 & 0.545 & $\mathrm{La}$ & 0.817 & 0.022 & 0.459 \\
\hline $\mathrm{Ce}$ & 0.685 & 0.084 & 0.577 & $\mathrm{Ce}$ & 0.707 & 0.116 & 0.595 \\
\hline $\mathrm{Sc}$ & 0.497 & 0.104 & 0.387 & $\mathrm{Sm}$ & 0.591 & 0.722 & 0.303 \\
\hline Th & 0.482 & 0.139 & 0.822 & $\mathrm{Sc}$ & 0.557 & 0.026 & 0.350 \\
\hline Eu & 0.439 & -0.882 & 0.111 & Th & 0.535 & 0.166 & 0.776 \\
\hline Sm & 0.350 & 0.890 & 0.226 & Eu & 0.200 & -0.978 & 0.014 \\
\hline
\end{tabular}

Absolute values above 0.3 are marked in bold

both glaciations, and the Ce concentration in the older tills (Wartanian Stadial of the Odranian Glaciation). The second factor accounts for only $9 \%$ of the REE concentration variation. It involves the Sm and Eu concentrations in both tills. The contribution of the effect of the third factor to the distribution of REE is only $3 \%$ in the tills of both glaciations. The concentrations of Th and $\mathrm{Ce}$ are related to the third factor.

The above factors affect the same (or very similar) elemental associations in the tills of both glaciations, which again points to similar conditions and processes affecting the formation of glacial tills of the youngest glaciations. These factors are of geogenic nature and are closely related to the processes of the acquisition of rock material (by glacial erosion and incorporation), its transport, deposition and diagenesis. During these processes and long-term weathering, both primary and secondary clay minerals become the most important source of REE (Polański, 1988; Kabata-Pendias and Mukherejee, 2007). Distinction $\mathrm{Eu}$ in the second factor and $\mathrm{Ce}$ and $\mathrm{Th}$ in the third factor shows a greater contribution of heavy minerals to the REE accumulation. Distribution of Sm and Eu in the tills analysed may be associated with the presence of monazite and bastnäsite, while Th may be linked with weathering-resistant minerals. Thorium bound in this form in a sedimentary and diagenetic environment is not mobilized, and the differences in the concentrations may reflect the contribution of detrital material to the rock mass (Krishnaswami, 1976; Cochran et al., 1986).

\section{DISCUSSION}

It should be borne in mind that the chemical and mineral composition of glacial tills depends mostly on the parent host bedrock of the Baltic Sea Basin and Scandinavia, eroded by the ice sheet. The outcrops of the bedrock show great lithological variability and occur at very different locations and to different extents. Parent rocks include outcrops of sedimentary rocks (Ordovician and Silurian limestone, marl, sandstones and shales; Cambrian shale, Devonian dolomite; Paleozoic sandstones and shales) dominant in the Baltic Sea Basin, Precambrian (mainly) igneous rocks (granitoids, diorite, syenite), metamorphic rocks (gneisses) and an allochthonous cover of Quaternary deposits (Jasiewicz, 2006). The similar concentrations of REE and Th (although slightly higher in the older, Wartanian tills) point to very similar conditions and formation processes, as well as a similar source material for Quaternary glacial tills of the youngest glaciations in Poland.

Lower concentrations of REE and Th in the youngest (Vistulian and Wartanian) tills of Poland compared to those from a part of the source area, i.e. the tills from the area of Sweden, can be attributed to intense weathering processes of source rock material both during southward transport and after deposition. The decisive factors in the mobilization of these elements were chemical weathering processes releasing REE (mainly from the surfaces of crystal structures) from minerals, causing depletion of the tills in the originally accumulated components.

The most important feature distinguishing between the two tills is the different distribution of REE fractions in the vertical sections. The maximum concentrations of LREE in the younger (Vistulian) tills are found in subsoil-1, and of HREE and Sc and Th in subsoil-2, while the highest concentrations of all these elements in the older (Wartanian) tills were determined in subsoil-1. This diversity could be used to determine the age of the tills in areas of uncertain stratigraphic position.

The significantly higher REE concentration in the tills of both glaciations in the eastern areas compared to the western regions suggests different positions of source areas for individual ice lobes. Similar conclusions are inferred from the analysis of mineral composition of the clay fraction, which does not change significantly due to the age of the tills and the depth of their occurrence, but changes due to their geographic position. In addition to illite and kaolinite, the tills from the eastern regions contain feldspars, carbonates, vermiculite, chlorite and amphiboles, while in the western areas, illite and kaolinite predominate in the clay fraction. Therefore, it can be thought that the diversity of the composition of the till analysed is less affected by the stratigraphic factor - their age (glaciation), but largely by the palaeogeographic factor - the extent and source area of a given ice lobe. The latitudinal variability of both the REE concentration and the mineral composition may indicate different compositions of the material transported by the various ice streams, and asynchronous propagation of glacial lobes across Poland (Marks, 2010).

In terms of REE and Th concentrations, the Vistulian and Wartanian tills are depleted compared to the standards of sedimentary rocks (normalization to NASC, PAAS), and enriched when compared to chondrite as well as to soils in northern Poland (FOREGS). Enrichment in the tills of the elements analysed relative to the soils is caused by weathering and pedogenetic processes that impoverish the surface layer (topsoil) in these elements. On the other hand, the enrichment relative to chondrite is probably associated with elevated REE concentrations in the source (Scandinavian) material. This is con- 
sistent with the positive Eu anomaly observed in the tills studied, which is unique in surface environments and is inherited from the parent (mainly igneous) rocks of the source area. Tills in Sweden (one of the main source areas) contain almost twice as much REE and Th as glacial tills in Poland, and the Eu anomaly in Sweden marks mineralisation zones. The following minerals are indicated as the source of Eu in these zones: allanite, bastnäsite, monazite, apatite, zircon and fluorite (Anderson et al., 2014).

\section{CONCLUSION}

Similar REE and Th concentrations, as well as insufficient data, do not allow using REE concentration variability as a good chronostratigraphic indicator unequivocally differentiating the youngest glacial tills: Vistulian (maximum stadial) and Odranian
(Wartanian Stadial). The observed east-west variability in the contents of elements analysed in the till of the same glaciation indicates the heterogeneity of the ice sheet which can be associated with various underlying lithologies traversed by different ice streams. A more promising research direction may be to use changes in REE concentration and mineral composition as tools of to constrain the movement of former ice streams (ice lobes).

Acknowledgements. The author thanks Dr. A. Pasieczna for substantive assistance in text preparation. Prof. L. Marks and Dr. K. Pochocka-Szwarc are acknowledged for „Quaternary consultations". I express profound gratitude to all the reviewers of this work - Prof. Z Migaszewski, Prof. S. Wołkowicz and anonymous reviewer for their insightful comments, important suggestions and help in the process of writing, and to the editor, Prof. T.M. Peryt, for his editorial assistance.

\section{REFERENCES}

Anderson, M., Carlsson, M., Landenberger, A., 2014. Geochemical Atlas of Sweden. Geological Survey of Sweden, Uppsala.

Aubert, D., Stille, P., Probst, A., 2001. REE fractionation during granite weathering and removal by waters and suspended loads: $\mathrm{Sr}$ and $\mathrm{Nd}$ isotopic evidence. Geochimica et Cosmochimica Acta, 65: 387-406.

Awwiller, D.N., 1994. Geochronology and mass transfer in Gulf Coast mudrocks (south-central Texas, USA): Rb-Sr, Sm-Nd and REE systematics. Chemical Geology, 116: 61-84.

Bojakowska, I., Lech, D., Karmasz, D., 2013. Rare earth elements in lake sediments in Poland. Goldschmidt Conference abstracts, Mineralogical Magazine, 77: 1562.

Bonnot-Courtois, C., 1981. Géochimie des terres rares dans les principaux milieux de formation et de sédimentation des argiles. Thesis of the University Paris Sud Orsay, Orsay.

Boulangé, B., Colin, F., 1994. Rare earth element mobility during conversion of nepheline syenite into lateritic bauxite at Passa Quatro, Minais Gerais, Brazil. Applied Geochemistry, 9: 701-711.

Braun, J.-J., Pagel, M., Muller, J.-P., Bilong, P., Michard, A., Guillet, B., 1990. Cerium anomalies in lateritic profiles. Geochimica et Cosmochimica Acta, 54: 781-795.

Braun, J.-J., Pagel, M., Herbillon, A., Rosin, C., 1993. Mobilization and redistribution of REEs and Thorium in a syenitic lateritic profile - a mass-balance study. Geochimica et Cosmochimica Acta, 57: 4419-4434.

Charewicz, W., Kowalski, W.W., Polański, A., 1990. Pierwiastki ziem rzadkich. WNT Warszawa, 2: 5-75.

Chase, J.W., Winchester, J.W., Coryell, C.D., 1963. Lanthanum, europium, and dysprosium distributions in igneous rocks and minerals. Journal of Geophysical Research U.S., 68: 567-575.

Chen, J., Yang, R., 2010. Analysis on REE geochemical characteristics of three types of REE-rich soil in Guizhou Province, China. Journal of Rare Earths, 28: 517-522.

Cochran, J.K., Carey, A.E., Sholkovitz, E.R., Surprenant, L.D., 1986. The geochemistry of uranium and thorium in coastal marine sediments and sediment pore waters. Geochimica et Cosmochimica Acta, 50: 663-680.

Compton, J.S., White, R.A., Smith, M., 2003. Rare earth element behavior in soils and salt pan sediments of a semi-arid granitic terrain in the Western Cape, South Africa. Chemical Geology, 201: 239-255.

De Vos, W., Tarvainen, T., Salminen, R., Reeder, S., De Vivo, B., Demetriades, A., Pirc, S., Batista, M.J., Marsina, K., Ottesen, R.T., O'Connor, P.J., Bidovec, M., Lima, A., Sieweers, U., Smith, B., Taylor, H., Shaw, R., Salpeteur, I., Gregorau- skiene, V., Halamic, J., Slaninka, I., Lax, K., Gravesen, P., Birke, M., Breward, N., Ander, E.L., Jordan, G., Duris, M., Klein, P., Locutura, J., Bel-Lan, A., Pasieczna, A., Lis, J., Mazreku, A., Gilucis, A., Heitzmann, P., Klaver, G., Petersell, V., 2006. Geochemical Atlas of Europe Part 2 - Interpretation of Geochemical Maps, Additional Tables, Figures, Maps and Related Publications. Geological Survey of Finland, Espoo, 1-690: 305-310.

Długosz, J., 2002. Differentiation of the composition of clay minerals in fine clay fraction $(<0.2 \mu \mathrm{m})$ of alfisols formed from glacial till, no 104 (in Polish with English summary). University of Science and Technology, Bydgoszcz.

Duddy, L.R., 1980. Redistribution and fractionation of rare-earth and other elements in a weathering profile. Chemical Geology, 30: 363-381.

Duczmal-Czernikiewicz, A., 2012. Rare earth elements in selected clay deposits of the Polish Lowland (Neogene). Biuletyn Państwowego Instytutu Geologicznego, 448: 419-430.

Elderfield, H., Upstill-Goddard, R., Sholkovitz, Er., 1990. The rare earth elements in rivers, estuaries, and coastal seas and their significance to the composition of ocean waters. Geochimica et Cosmochimica Acta, 54: 971-991.

Fedele, L., Plant, J.A., De Vivo, B., Lima, A., 2008. The rare earth element distribution over Europe: geogenic and anthropogenic sources. Geochemistry: Exploration, Environment, Analysis, 8: 3-18.

Gnandi, K., Tobschall, H.J., 2003. Distribution patterns of rare-earth elements and uranium in tertiary sedimentary phosphorites of Hahotoe-Kpogame, Togo. Journal of African Earth Sciences, 37: 1-10.

Galán, E., Fernández-Caliani, J.C., Miras, A., Aparicio, P., Márquez, M.G., 2007. Residence and fractionation of rare earth elements during kaolinization of alkaline peraluminous granites in NW Spain. Clay Minerals, 42: 341-352.

Galbarczyk-Gąsiorowska, L., 2010. Rare Earth Element mobility in a weathering profile - a case study from the Karkonosze Massif (SW Poland). Acta Geologica Polonica, 60: 599-616.

Gałązka, D., Marks, L., Zabielski, R., 1999. Is a lithostratigraphic correlation of tills useful for the Quaternary stratigraphy of Poland? (in Polish with English summary). Przegląd Geologiczny, 47: 261-265.

Gromet, L.P., Dymek, R.F., Haskin, L.A., Korotev, R.L., 1984. The "North American Shale Composite": its compilation, major and trace element characteristics. Geochimica et Cosmochimica Acta, 48: 2469-2482. 
Henderson, P., 1984. Rare Earth Element Geochemistry. Elsevier, Amsterdam.

INSTRUKCJA opracowania i wydania szczegółowej Mapy Geologicznej Polski w skali 1:50 000, 2004. (in Polish) Państwowy Instytut Geologiczny, Warszawa.

IUAPC - International Union of Pure and Applied Chemistry, 1970. Nomenclature of inorganic chemistry. Issued by the Commission on the Nomenclature of Inorganic Chemistry, London.

Jasiewicz, J., 2006. The mechanism of forming the petrographic composition of last glacial's moranic till on Peribaltic area - a current interpretative problems (in Polish with English summary). Badania Fizjograficzne Nad Polską Zachodnią, Seria AGeografia Fizyczna, 57: 61-82.

Kabata-Pendias, A., Mukherjee, A.B., 2007. Trace Elements from Soil to Human. Springer, Berlin.

Kanazawa, Y., Kamitani, M., 2006. Rare earth minerals and resources in the world. Journal of Alloys and Compounds, 408: $1339-1343$.

Kenig, K., 2009. Lithology of tills in the Polish Lowlands - basic investigative methods (in Polish with English summary). Biuletyn Państwowego Instytutu Geologicznego, 437: 1-58.

Krishnaswami, S., 1976. Authigenic transition elements in Pacific pelagic clays. Geochimica et Cosmochimica Acta, 40: 425-434.

Laveuf, C., Cornu, S., 2009. A review of Rare Earth Elements to trace pedogenetic processes. Geoderma, 154: 1-12.

Lindner, L., Marks, L., 2012. Climatostratigraphic subdivision of the Pleistocene Middle Polish Complex in Poland (in Polish with English summary). Przegląd Geologiczny, 60: 36-45.

Lis, J., Pasieczna, A., 1995. Geochemical Atlas of Poland 1:2500 000. Państwowy Instytut Geologiczny, Warszawa.

Lisicki, S., 2003. Lithotypes and lithostratigraphy of tills of the Pleistocene in the Vistula drainage basin area, Poland (in Polish with English summary). Prace Państwowego Instytutu Geologicznego, 177: 1-105.

Ma, Y.-J., Huo, R.-K., Liu, C.-Q., 2002. Speciation and fractionation of rare earth elements in a lateritic profile from southern China: Identification of the carriers of $\mathrm{Ce}$ anomalies. Goldschmidt Conference Abstracts, Davos, Switzerland. Geochimica et Cosmochimica Acta, 66 Supplement 1: 471.

Małecka, K., 2012. Zmienność geochemiczna lekkich i ciężkich pierwiastków ziem rzadkich w osadach wybranych jezior polodowcowych w Polsce (in Polish). Ph.D thesis, Faculty of Geology, University of Warsaw.

Marks, L., 2002. Last Glacial Maximum in Poland. Quaternary Science Reviews, 21: 103-110.

Marks, L., 2005. Pleistocene glacial limits in the territory of Poland. Przegląd Geologiczny, 53: 988-993.

Marks, L., 2010. Chronostratigraphic setting of the Neogene/Quaternary boundary (in Polish with English summary). Biuletyn Państwowego Instytutu Geologicznego, 438: 93-98.

Mazerski, J., 2009. Chemometria praktyczna - interpretuj wyniki swoich pomiarów (in Polish). Wydawnictwo Malamut.

McDonough, W.F., Sun, S.-S., 1995. The composition of the Earth. Chemical Geology, 120: 223-253.

McLennan, S.M., Taylor, S.R., 2012. Geology, geochemistry, and natural abundances of the rare earth elements. In: The Rare Earth Elements (ed. D.A. Atwood): 1-19, John Wiley and Sons.

Migaszewski, Z.M., Gałuszka, A., 2015. The characteristics, occurrence, and geochemical behaviour of rare earth elements in the environment: a review. Critical Reviews in Environmental Science and Technology, 45: 429-471.
Nakamura, N., 1974. Determination of REE, Ba, Fe, Mg, $\mathrm{Na}$ and $\mathrm{K}$ in carbonaceous and ordinari chondrites. Geochemica et Cosmochimica Acta, 44: 287-308.

Nesbitt, H.W., 1979. Mobility and fractionation of rare earth elements during weathering of a granodiorite, Nature, 279: 206-210.

Nesbitt, H.W., Markovics, G., 1997. Weathering of granodioritic crust, long-term storage of elements in weathering profiles, and petrogenesis of siliciclastic sediments. Geochimica et Cosmochimica Acta, 61: 1653-1670.

Nyakairu, G.W.A., Koeberl, C., 2001. Mineralogical and chemical composition and distribution of rare earth elements in clay-rich sediments from central Uganda. Geochemical Journal, 35: 13-28.

Öhlander, B., Land, M., Ingri, J., Widerlund, A., 1996. Mobility of rare earth elements during weathering of till in northern Sweden. Applied Geochemistry, 11: 93-99.

Panahi, A., Young, G.M., Rainbird, R.H., 2000. Behavior of major and trace elements (including REE) during Palaeoproterozoic pedogenesis and diagenetic alteration of an Archaean granite near Ville Marie, Quebec, Canada. Geochimica et Cosmochimica Acta, 64: 2199-2220.

Polański, A., 1988. Podstawy Geochemii (in Polish). Część II, Rozdział 13 - Skandowce: 494-505. Wydawnictwo Geologiczne, Warszawa.

Reeder, R.J., America, M.S.O., 1983. Carbonates: mineralogy and chemistry. Reviews in Mineralogy, 11.

Ryder, P., Nowak, M., 2015. Review of the major minerals of rare earth elements - gold of the 21st century (in Polish with English summary). Przegląd Geologiczny, 63: 348-362.

Singh, P., Rajamani, V., 2001. REE geochemistry of recent clastic sediments from the Kaveri floodplains, Southern India: implication to source area weathering and sedimentary processes. Geochimica et Cosmochimica Acta, 65: 3093-3108.

Systematyka gleb Polski, 2011. (in Polish) Roczniki gleboznawcze 62, 3 (Polish soil classification), 2011. Roczniki Gleboznawcze Soil Science Annual, 62: 1-193.

Taunton, A.E., Welch, S.A., Banfield, J.F., 2000. Geomicrobiological controls on light rare earth elements, $\mathrm{Y}$ and $\mathrm{Ba}$ distributions during granite weathering and soil formation. Journal of Alloys and Compounds, 303-304: 30-36.

Taylor, S.R., McLennan, S.M., 1985. The Continental Crust: its Composition and Evolution. Blackwell Scientific Publications, Oxford, U.K.

Taylor, S.R., McLennan, S.M., 2009. Planetary Crusts: their Composition, Origin and Evolution. Cambridge University Press.

Terekhov, E.N., Shcherbakova, T.F., 2006. Genesis of positive Eu anomalies in acid rocks from the Eastern Baltic Shield. Geochemistry International, 44: 439-455.

Topp, S.E., Salbu, B., Roaldset, E., Jørgensen, P., 1984. Vertical distribution of trace elements in laterite soil (Suriname). Chemical Geology, 47: 159-174.

Towell, D.G., Spirn, R.V., Winchester, J.W., 1969. Europium anomalies and the genesis of basalt: a discussion. Chemical Geology, 4: 461-464.

Xing, B., Dudas, M.J., 1993. Trace and rare earth element content of white clay soils of the Three River Plain. Heilongjiang Province, P.R. China. Geoderma, 58: 181-199.

Zepf, V., 2013. REE - a New Approach to the Nexus of Supply, Demand and Use: Exemplified Along the Use of Neodymium in Permanent Magnets. Springer Theses. 